Ks. Krzysztof TYBUROWSKI

(Kraków, UPJPII)

\title{
WZAJEMNA WIERNOŚĆ MAŁŻEŃSKA W NAUCZANIU JANA CHRYZOSTOMA
}

Do problemu ludzkiej seksualności i jej kontroli, z którą w sposób konieczny wiąże się zagadnienie wierności małżeńskiej, różnie podchodziła starożytna teologia chrześcijańska: generalnie kwestia ta była powodem wielu kłopotów interpretacyjnych. Dziedzina, jaką jest seksualność, sprawiająca człowiekowi tak wiele trudności i tak bardzo narażana na nadużycia i grzechy, wielokrotnie była przedmiotem interpretacji patrystycznych. Niektórzy widząc niejako jej wszechobecność w ludzkim życiu, skłaniali się nawet do identyfikowania jej z upadkiem Adama i, w konsekwencji, do przeniknięcia nią całej upadłej ludzkiej natury. Myśl taka odbija się mocnym echem przede wszystkim w teologii judaistycznej. Natomiast w chrześcijaństwie pojawia się rzadziej, generalnie jednak jako nurt heterodoksyjny.

Tak właśnie patrzy Filon Aleksandryjski na treść występku Adama, jakoby było nim wykrocznie natury seksualnej. Twierdzi on, że wszystko ma początek w pożądaniu cielesnym, które stało się źródłem niegodziwości i przestępstw ${ }^{1}$. Dotykając zaledwie myśli tych, którzy przyjęli taką interpretację grzechu pierwszych rodziców, należałoby wspomnieć o palestyńskim apokryfie, znanym pod nazwą Apokalipsy Abrahama, w której Adam wraz z Ewą mieliby zgrzeszyć zbliżeniem cielesnym w obecności szatana, nazwanego w apokryfie Azazelem² ${ }^{2}$. Niektóre pierwotne sekty chrześcijańskie, bądź powołujące się przynajmniej na przekaz biblijny, mniej lub bardziej związane ze starożytną gnozą, bądź manicheizmem, na przykład tzw. enkratyci, zwani inaczej wstrzemięźliwymi ${ }^{3}$ mocno podkreślały koncepcję, że grzech pierwszych rodziców był występkiem natury seksualnej. Deprecjonowali oni materię, a co za tym idzie,

\footnotetext{
${ }^{1}$ Por. Philo Alexandrinus, De opificio mundi 151-156, ed. R. Arnaldez, w: Les oeuvres de Philon d'Alexandrie, I, Paris 1961, 242-246, thum. L. Joachimowicz: Filon Aleksandryjski, Pisma I, Warszawa 1986, 74-76; zob. J.B. Frey, L'état originel et la chute de l'homme d'après les conceptions juives au temps de Jésus Christ, RSPhTh 5 (1911) 507-545, spec. 526-527 i 531.

${ }^{2}$ Por. Apocalypsis Abrahae 23-24, tłum. R. Rubinkiewicz, w: Apokryfy Starego Testamentu, Warszawa 1999, 453-454; Frey, L'état originel, s. 527.

${ }^{3}$ Więcej na temat sekty por. F. Bolgiani, Encratismo, DPAC I 1151-1152; zob. także W. Łydka, Enkaratyci, EK IV 1108.
} 
potępiali życie małżeńskie, naciskając bardzo w swoim nauczaniu na ukazywanie grzechu Adama jako nadużycia o charakterze seksualnym. Podobnie ustosunkowują się do tego problemu członkowie ruchu monastycznego zwani mesalianami ${ }^{4}$. Uważali oni, że sam grzech Adama był czynem o treści seksualnej, który pozostawił poprzez przechodzenie na wszystkich potomków Adama swoją konsekwencję w postaci pożądliwości, która z kolei trzyma w niewoli każdego, i nie jest jej w stanie zgładzić nawet chrzest. Można ją jednak kontrolować poprzez wyjątkową ascezę, ta zaś przede wszystkim wyrażałaby się w odrzuceniu współżycia płciowego ${ }^{5}$. Inne ponadto prądy starożytnych herezji skłaniały się do postrzegania grzechu Adama w podobnych kategoriach ${ }^{6}$.

$\mathrm{Z}$ czasem odchodzono od tak skrajnego patrzenia. Proces ten można zauważyć chociażby u Klemensa Aleksandryjskiego, który nie ma już tak rygorystycznego spojrzenia, twierdząc, że bezpośrednim przewinieniem nie jest samo zło seksualności, ale jej przedwczesny usus w odniesieniu do czasu, jaki dla jej zastosowania przewidział sam Bóg ${ }^{7}$. Takie podejście do przewinienia pierwszych rodziców nie posiada de facto uzasadnienia biblijnego. Rozumowanie to jest bardziej oparte na obserwacji życia człowieka, a także jego wyjątkowej słabości $\mathrm{w}$ dziedzinie nieuporządkowanego ulegania popędowi płciowemu ${ }^{8}$.

1. Kwestia seksualności w rozumieniu Jana Chryzostoma. Jan Chryzostom, co prawda, nie identyfikuje grzechu Adama z występkiem natury seksualnej, jednak ukazuje samą seksualność jako pewnego rodzaju konsekwencję pierwszego grzechu. W zamierzeniu Boga, jak twierdzi Jan, człowiek miał być dziewiczy. Dziewictwo człowieka, który przecież został stworzony na obraz Boży, miało być właśnie odbiciem dziewictwa Boga, jego apathei i braku jakiegokolwiek zepsucia9 ${ }^{9}$ Tak więc seksualność człowieka nie jest zgodna, według Jana, z pierwotnym zamiarem Boga, ale w gruncie rzeczy jest konsekwencją grzechu. Chryzostom w tym kontekście podkreślał będzie wyższość dziewictwa i serdecznie do niego zachęcał.

${ }^{4}$ Więcej na temat mesalian por. Marcus Eremita, Responsio ad eos qui de divino baptismate dubitant, PG 65, 985-1028; zob. P.F. Beatrice, Tradux peccati. Alle fonti della dottrina agostiniana del peccato originale, Studia Patristica Mediolanensia 8, Milano 1978, 236-237 i 239-240; J. Gribomont, Messaliani, DPAC II 2238-2239; SWP 282-282.

${ }^{5}$ Por. K. Tyburowski, Przedmiot grzechu Adama w myśli Ambrozjastra na tle wspótczesnego mu status quaestionis, SSan 10 (2003) 242-245.

${ }^{6}$ Por. Beatrice, Tradux peccati, s. 222-223.

${ }^{7}$ Por. Clemens Alexandrinus, Stromata III 94, 3, GCS 52, 239, thum. J. Niemirska-Pliszczyńska: Klemens Aleksandryjski, Kobierce, I, Warszawa 1994, 284; Beatrice, Tradux peccati, s. 225.

${ }^{8}$ Więcej na ten temat por. Tyburowski, Przedmiot grzechu Adama w myśli Ambrozjastra, s. 244-245.

${ }^{9}$ Por. J. Krykowski, Nauka o matżeństwie, rodzinie i wychowaniu (Wstęp), w: Św. Jan Chryzostom, O matżeństwie, wychowaniu dzieci i ascezie, BOK 19, Kraków 2002, 24. 
Jan jest jednak realistą i wie, że praktyka życia pokazuje, iż do dziewictwa nie wszyscy w praktyce są zdolni. Stąd Bóg tylko niektórych obdarza specjalną łaską i powołuje ich do dziewiczego życia. Dziewictwo, które przed grzechem Adama było czymś naturalnym, nie jest więc już obowiązkiem dla skażonej natury, ale radą, do praktykowania której nikogo nie można zmusić10. Chryzostom nie ulega więc pokusie deprecjonowania małżeństwa i jego seksualnego wymiaru. Nawet w swoim traktacie De virginitate docenia małżeństwo i broni je przed błędnymi naukami, w których jest ono potępiane. Deprecjacja małżeństwa bowiem jest - jak twierdzi Chryzostom - także w ostatecznej konsekwencji umniejszeniem chwały dziewictwa ${ }^{11}$. Małżeństwo więc nie układa się jak biegun przeciwny dziewictwa, w przypadku takim byłoby bowiem złem. Jest ono jednak dobrem, choć niższym niż dziewictwo ${ }^{12}$. Jan naucza, że mimo iż seksualność jest związana z konsekwencjami grzechu, to jednak jest objęta miłosierdziem i opatrznością Bożą, i w jakimś sensie jej uporządkowanie Bóg skierował w ramy instytucji małżeństwa ${ }^{13}$. W powierzeniu seksualności małżeństwu Chryzostom widzi niejako jeszcze jeden dowód na paradoksalność działania Boga, który, jako jedyny, może ze zła wyprowadzić dobro. Człowiek miał być dziewiczy, pojawiła się jednak w wyniku grzechu Adama pożądliwość, jako coś zdecydowanie negatywnego, wobec tego Bóg zechciał ją wykorzystać do powołania nowego dobra.

\section{Formacja do czystości przedmałżeńskiej - gwarancja wierności} w małżeństwie. Małżeństwo właśnie stało się pewną formą remedium na to, by pożądliwość ludzka została opanowana i skierowana na właściwe tory. Stało się ono środkiem przeciwko rozwiązłości, niewstrzemięźliwości i grzechom przeciwko naturze ${ }^{14}$. I to jest w przepowiadaniu Chryzostoma główny cel małżeństwa. Jan dlatego chociażby zachęca rodziców, aby trzymali pod kontrolą swoje dorastające dzieci: nie wypuszczali bez potrzeby córek z domu ${ }^{15}$, ani nie dawali zbytniej wolności synom, choć ci, siłą rzeczy częściej muszą wycho-

${ }^{10}$ Por. Joannes Chrysostomus, In Matthaeum hom. 78, 1, PG 58, 711, tłum. J. Krystyniacki, ŹMT 23, 417; tamże 62, 3-4, PG 58, 600, ŹMT 23, 249-252; tenże, De virginitate 76, 1, SCh 125, 365.

${ }^{11}$ Por. np. De virginitate 10, 1, SCh 125, 123; 1, 2, SCh 125, 95; 1, 4, SCh 125, 97; tenże, In epistulam 1 ad Corinthios hom. 19, 6, PG 61, 160.

12 Por. tenże, In illud: „Vidi Dominum” hom. 3, 3, PG 56, 116: „Bonum est coniugium, sed melior est virginitas: nec quoniam melior est virginitas, ideo malum est coniugium, sed illud quidem inferius, alioqui bonum et ipsum"; tenże, De virginitate 9, 1, SCh 125, 121; 10, 1, SCh 125, 123.

${ }^{13}$ Por. De virginitate 14, 3-5, SCh 125, 141-142.

${ }^{14}$ Por. In illud: „Propter fornicationes uxorem unusquisque habeat”, PG 51, 207-218; De virginitate 39, 2, SCh 125, 231; tenże, Adversus oppugnatores vitae monasticae III 8, PG 47, 360; tenże, In epistulam ad Romanos hom. 4, 1, PG 60, 417; tenże In epistulam 1 ad Corinthios hom. 19, 1, PG 61, 151.

${ }^{15}$ Por. tenże, In illud: „Propter fornicationes uxorem unusquisque habeat” 1, 2, PG 51, 211; tenże, De SS. Berenice et Prosdoce 4, PG 50, 636. 
dzić z domu, choćby w celach kształcenia się. Zbytnia swoboda bowiem dana dorastającym jest przyczyną rozwiązłości i większej podatności na cudzołóstwo w przyszłym małżeństwie ${ }^{16}$. Rodzice powinni dać dzieciom odpowiednią formację w dziedzinie czystości i strzec swoich dorastających synów przed niepotrzebnym spotykaniem się z kobietami. W związku z tym, w domu, gdzie zamieszkują wchodzący w dorosłość chłopcy, nawet ewentualna opiekunka powinna być w starszym wieku ${ }^{17}$. Zachęca więc Chryzostom rodziców, aby w miarę szybko żenili i wydawali za mąż swoje dzieci, by w ten sposób uchronić ich od grzechu nieczystego ${ }^{18}$. Bardzo mocno podkreśla Jan rolę czystości przedmałżeńskiej we właściwym funkcjonowaniu przyszłego małżeństwa. Brak kontaktu seksualnego przed zawarciem małżeństwa wytworzy bowiem w umyśle młodego człowieka naturalną predylekcję do zachowania wierności w małżeństwie i nie otworzy, jakże niebezpiecznej, furtki do cudzołóstwa. Odpowiednia więc formacja dorastającej młodzieży ze strony rodziców jest fundamentem ich przyszłej wierności, a co za tym idzie, szczęścia małżeńskiego $^{19}$. Rodzice ponadto mają aktywnie partycypować w wyborze współmałżonka dla swego dziecka. Syn ma się poważnie liczyć ze zdaniem rodziców, którzy mają szczególną współodpowiedzialność za właściwy wybór żony dla niego. Ten jednak powinien być uległym wobec woli rodziców, szczególnie ojca $^{20}$, córka natomiast powinna całkowicie zdać się na postanowienia rodziców w wyborze partnera życiowego ${ }^{21}$.

Także samo małżeństwo jest piękne - mówi Jan - ponieważ trzyma człowieka w czystości i chroni go przed upadkiem w przepaść rozwiązłości i przed zatraceniem się $w$ niej $^{22}$. Właściwe przygotowanie do małżeństwa, a $\mathrm{i}$ ono samo przede wszystkim, w zasadniczym stopniu chroni człowieka przed grzechem nieczystym. Małżeństwo jest, co prawda, niżej postawione w hierarchii doskonałości niż dziewictwo, to bowiem ostatnie bezpośrednio niejako kieruje człowieka ku świętości ${ }^{23}$. Wynikałoby z takiego rozumowania, że małżeństwo z trudnością może człowieka doprowadzić do świętości. Jan istotnie tak

\footnotetext{
${ }^{16}$ Por. tenże, In Matthaeum hom. 59, 7, PG 58, 583, ŹMT 23, 224-225.

${ }^{17}$ Obszernie na temat wychowania dzieci w atmosferze domowej por. P. Rentinck, La cura pastorale in Antiochia nel IV secolo, Roma 1970, 27-28.

${ }^{18}$ Por. tamże, s. 252.

${ }^{19}$ Por. Joannes Chrysostomus, In epistulam 1 ad Timotheum hom. 9, 2, PG 62, 546, thum. T. Sinko: Św. Jan Złotousty, Homilie na listy pasterskie św. Pawła, Kraków 1949, 98-99; tenże, De Anna sermo 1, 6, PG 54, 642.

${ }^{20}$ Por. tenże, Expositio in Ps. 48, 7, PG 55, 509; tenże, De virginitate 57, 2, SCh 125, 309-311; tenże, Cathechesis 1, 14, SCh 50, 116.

${ }^{21}$ Por. tenże, De virginitate 57, 1, SCh 125, 309.

${ }^{22}$ Por. tamże 39, 2, SCh 125, 231; 9, 1, 27 i 33-34, SCh 125, 121, 181 i 199-201; tenże, Adversus oppugnatores vitae monasticae 3, 8, PG 47, 360; tenże, In epistulam ad Romanos hom. 4, 1-3, PG 60, 417-419.

${ }^{23}$ Por. tenże, De virginitate 30, 2, SCh 125, 191.
} 
uważał w swojej wczesnej działalności pisarskiej w traktacie De virginitate, później natomiast, nabrawszy większej życiowej mądrości, już tak zdaje się nie twierdzić. W swoich homiliach nie dokonuje już gradacji, który szlak do doskonałości byłby lepszy, ale wprost mówi o różnych drogach dochodzenia do świętości ${ }^{24}$, z których nie jest wykluczone i małżeństwo, i o różnych stopniach cnoty, którymi lśni całe Ciało Chrystusa ${ }^{25}$.

Życie małżeńskie też jest drogą, która w zamiarach Bożych prowadzić ma do zbawienia, i choć więcej narażone jest na niebezpieczeństwa niż dziewictwo, może bowiem być źle przeżywane, to jednak jest drogą pewną, jeśli będzie małżeństwem czystym, przenikniętym wiernością. Jan rozróżnia wyraźnie pomiędzy dziewictwem, a czystością. Małżonkowie bowiem, choć nie żyją w dziewictwie, powołani są jednak do życia w czystości, którą rozumie jako uporządkowanie w dziedzinie seksualności ${ }^{26}$. Czystość małżeńska sprawia właśnie, że wzrasta i pogłębia się miłość małżeńska, zdolność do ofiary i wszelkie inne dobra ${ }^{27}$. Właśnie małżeństwo jest niejako sakramentem udzielającym człowiekowi łaski, która pomaga porządkować tę szczególnie narażoną na nadużycia dziedzinę. Małżonkowie, żyjąc ciągle przy sobie, wspomagają się we wzajemnej kontroli swej seksualności. Jakkolwiek tę właśnie dziedzinę obydwoje przeżywają różnie, to jednak zarówno mężczyzna jak i kobieta w małżeństwie powołani są do jednakowo rozumianej czystości ${ }^{28}$. Akt seksualny w kontekście małżeństwa nie pociąga za sobą żadnej nieczystości, nie jest więc żadnym grzechem, nie posiada w sobie żadnej niegodziwości. Współżycie seksualne zresztą samo w sobie nie jest grzechem, jego ewentualna grzeszność nie wynika z jego natury, ale ze złego jego użytku. Źle użyte staje się grzechem przede wszystkim przeciwko Bogu, ale także przeciwko miłości bliźniego, zarówno wobec współmałżonka, jak i osoby, z którą się grzeszy ${ }^{29}$.

3. Wierność małżeńska - podstawa małżeńskiego szczęścia. Małżeństwo, choć jest zasadniczą pomocą we właściwym korzystaniu z popędu płciowego, jednak nie chroni całkowicie człowieka przed nieuporządkowaniem w tej dziedzinie i nie zamyka go na niebezpieczeństwa. Dlatego wierność małżeńska i praca nad nią jest tematem, który Jan porusza stosunkowo często w swojej działalności duszpasterskiej.

${ }^{24}$ Por. tenże, In Matthaeum hom. 44, 4, PG 57, 469, ŹMT 23, 49; 45, 2, PG 58, 474, ŹMT 23 , 55; tenże, Expositio in PS. 127, 2, PG 55, 367.

${ }^{25}$ Por. tenże, In epistulam 1 ad Corinthios hom. 30, 4, PG 61, 254.

${ }^{26}$ Por. tenże, In Matthaeum hom. 7, 7, PG 57, 81, ŹMT 18, 100; tenże, In Genesin hom. 59, 3, PG 54, 517-518.

${ }^{27}$ Por. tenże, In illud: „Propter fornicationes uxorem unusquisque habeat” 1, 4, PG 51, 215.

${ }^{28}$ Por. tamże 1, 4, PG 51, 214; 1, 5, PG 51, 218; tenże, In epistulam 1 ad Corinthios hom. 19, 1, PG 61, 152.

${ }^{29}$ Por. tenże, In epistulam ad Titum hom. 4, 5, PG 62, 682, thum. T. Sinko, s. 343. 
W Bożym zamiarze małżeństwo jest skierowane na monogamię. Małżonkowie wraz z przyjęciem sakramentu małżeństwa należą już nie do siebie samych, ale do siebie nawzajem. Ta zasada dotyczy przede wszystkim prawa do ciała ${ }^{30}$. Prawo to rozciąga się także na dziedzinę intencji. Jest tak bardzo wymagające, że nawet spojrzenie nieczyste jest zakazane przez Pana $^{31}$, ono bowiem wzbudza pożądliwość i może prowadzić do cudzołóstwa $^{32}$. Delikatna sfera seksualna w kontekście małżeństwa jest szczególnie narażona na grzech zazdrości. Powinno się więc unikać wszystkiego, co może budzić podejrzenie u współmałżonka, z drugiej jednak strony Jan przestrzega przed zazdrością i chorobliwą w tej dziedzinie podejrzliwością. Tego typu bowiem zachowania prowadzić mogą i często prowadzą do ruiny życia małżeńskiego ${ }^{33}$. Chryzostom więc przestrzega przed łatwym dawaniem wiary plotkom, a i chrześcijan przestrzega przed powtarzaniem zasłyszanych dykteryjek ${ }^{34}$. Często się zdarza jednak, że plotki mają swoją podstawę w rzeczy, w środowisku bowiem miejskim, jakim była Antiochia czy Konstantynopol, zdrady zdarzały się nagminnie, szczególnie ze strony mężczyzn. W sprzyjaniu rozwiązłości jako główną przyczynę Jan postrzega chodzenie do teatru ${ }^{35}$. Chrześcijaństwo pierwszych wieków patrzyło z wielką podejrzliwością na spectacula, o czym świadczą liczne dzieła Ojców przeciwne uczestnictwu $\mathrm{w}$ przedstawieniach teatralnych. Poza różnymi aspektami sprzecznymi z wiarą chrześcijańską w sztukach teatralnych, w czasach Jana Chryzostoma instytu-

${ }^{30}$ Por. tenże, De non iterando coniugio 2, PG 48, 612: „ea quae nupta est, uno viro contenta est"; tenże, Adversus oppugnatores vitae monasticae III 17, PG 47, 379; tenże, In epistulam 1 ad Thessalonicenses hom. 5, 2, PG 62, 424.

31 Por. tenże, Expositio in Ps. 44, 9, PG 55, 182; tenże, In Matthaeum hom. 17, 1-3, PG 57, 255-259, ŹMT 18, 214-219.

32 Por. In Matthaeum hom. 17, 1, PG 57, 256: „nam si formosas intueri faciem student, ille praecipue vitii fornacem accendit, animamque captivam efficit, et cito ad opus quoque accedet", thum. ŹMT 18, 215; zob. tenże, De poenitentiae 6, 2, PG 49, 316.

${ }^{33}$ Por. tenże, De virginitate 52, SCh 125, 289-299; tenże, In Genesin hom. 56, 1, PG 54, 487.

${ }^{34}$ Por. tenże, In epistulam ad Ephesios hom. 20, 6, PG 62, 143: „Nullus fidelis maritum apud uxorem calumnietur: sed neque vir leviter et inconsiderate credat adversus uxorem: neque uxor leviter et curiose scrutetur ingressus et exitus: sed neque maritus seipsum praebeat signum suspicione"; R. Rentinck, La cura pastorale, s. 268-273 (La fedeltà coniugale); C. Scaglioni, Ideale coniugale e familiare in san Giovanni Crisostomo, w: Etica sessuale e matrimonio nel cristianesimo delle origini, ed. R. Cantalamessa, Milano 1976, 273-422, spec. 282-345 (Il rapporto marito - moglie).

35 Por. tenże, In Matthaeum hom. 37, 6, PG 57, 427: „undenam ii qui nuptiis insidias parant? nonne ab hac scena? unde ii qui thalamos effodiunt? nonne ab orchestra illi? nonne hinc viri uxoribus sunt molesti? nonne hinc a viris uxores despiciuntur? nonne hinc moechi plurimi?", tłum. ŹMT 18, 440, tenże, De Davide et Saule hom. 3, 1, PG 54, 696; zob. S. Longosz, Widowiska teatralne zagrożeniem dla życia rodzinnego według św. Jana Chryzostoma, w: Chrześcijanie a życie publiczne w Cesarstwie Rzymskim III-IV wieku, red. J. Śrutwa, Lublin 1988, 135-198; W. Myszor, Teatr $i$ widowiska w ocenie greckich pisarzy kościelnych, tamże, s. 123-134. 
cja teatru przeżywała ponadto prawdziwą dekadencję, w której niemoralność seksualna często się pojawiała.

Wierność małżeńska, jak podkreśla Chryzostom, jest zagrożona przede wszystkim przez dwa rodzaje grzechów: rozwiązłość i cudzołóstwo. Chryzostom jest bardzo praktyczny w przestrzeganiu przed tymi nadużyciami. Odwołuje się nie tyle do obrazy, jaką ten grzech wyrządza Bogu, ale do konsekwencji codziennych, do jakich może doprowadzić rozwiązłość i cudzołóstwo w życiu małżeńskim i rodzinnym.

Rozwiązłość jest wynalazkiem diabła i doskonałym narzędziem zaślepienia umysłu ulegającemu jej człowieka. Doprowadzić może nawet do zabójstwa $^{36}$. Cudzołóstwo jest grzechem gorszym od kradzieży, ponieważ kradzież można zrekompensować, cudzołóstwo natomiast pozostawia trwałe ślady i ra$n y^{37}$. Doprowadza ono bowiem często do poczęcia nieślubnego dziecka, które to dziecko zmuszone będzie nosić na sobie skutki czynu ojca, czy matki w postaci złej sławy ${ }^{38}$. Cudzołóstwo, niezależnie do wspomnianych oczywistych konsekwencji jest jednak przede wszystkim obrazą Boga i zamyka człowiekowi drogę do zbawienia, niezależnie od dobra, jakie sprawca tego grzechu w swoim życiu mógł dokonać ${ }^{39}$.

Chryzostom pracuje wytrwale nad zmianą skażonej mentalności swoich podopiecznych $\mathrm{w}$ tej dziedzinie; otóż $\mathrm{w}$ ocenie cudzołóstwa jasno rozróżnia pomiędzy legislacją świecką, a prawodawstwem Bożym. Prawo świeckie za grzech ten karało tylko kobietę, natomiast Bóg inaczej ocenia ten czyn. Zarówno kobieta jak i mężczyzna są przed Bogiem traktowani jednakowo i jednakową ponoszą karę: wykluczenie z Królestwa Bożego ${ }^{40}$. Ponadto Jan łamie także powszechne przekonanie, jakoby grzech żonatego mężczyzny był mniejszy, jeśli ten zgrzeszy z kobietą niezamężną ${ }^{41}$. Jednak nawet prawodawstwo kościelne karało bardziej cudzołóstwo, niż grzech nieczysty popełniony

\footnotetext{
${ }^{36}$ Por. tenże, In Matthaeum hom. 48, 4, PG 58, 492: „talis est fornicatio non lascivis tantum, sed et homicidos efficit", thum. ŹMT 23, 84; tenże, In epistulam 1 ad Corinthios hom. 11, 4, PG 61, 92.

${ }^{37}$ Por. tenże, In epistulam 1 ad Thessalonicenses hom. 5, 2, PG 62, 424: „quamobrem si cum altera concubitus est transgressio, et latrocinium, et fraus; imo vero est gravior quove latrocinio. Non enim adeo dolemus si nostrae auferuntur pecuniae, ut si nostrum matrimoniale perfodiatur cubile".

${ }^{38}$ Por. tenże, In epistulam ad Romanos hom. 24, 3, PG 60, 626, thum. T. Sinko: Św. Jan Chryzostom, Homilie na List św. Pawła do Rzymian, I/2, Kraków 1998, 377.

${ }^{39}$ Por. tenże, In Joannem hom. 63, 4, PG 59, 352: „sanctificationem appellat castitatem, ut unusquisque sua uxore contentus sit, neque aliam adeat. Nam qui sua contentus non est, salvus esse nequit: sed pereat oportet, etsi mille bonis operibus sit instructus".

${ }^{40}$ Por. tenże, In epistulam 1 ad Thessalonicenses hom. 5, 2, PG 62, 425: ,sicut enim hos punimus, quando nobiscum habitantes seipsas alias dederint: ita nos quoque punimur, si non a legibus, a Deo quidem certe"; por. tenże, In Joannem hom. 63, 4, PG 59, 352-354.

${ }^{41}$ Por. tenże, In illud: „Propter fornicationes uxorem unusquisque habeat” 1, 4, PG 51, 213 : „,non ignoramus plurimos adulterium arbitrari tantum, cum quis marito iunctam mulierem corrumpit: ego vero sive cum vulgari scorto, sive cum ancilla, sive cum alia quapiam muliere non maritata, illegitimo lascivoque congressu iungatur, cum uxorem habeat, adulterium hoc esse contendo"; por.
} 
poza kontekstem małżeństwa. Cudzołóstwo bowiem wymierzone jest bezpośrednio $w$ jedność małżeństwa i rodziny ${ }^{42}$. Kary kościelne wykluczały takiego grzesznika z Kościoła i zakazywały mu udziału w nabożeństwach, aby nie być złym przykładem dla pozostałych wiernych ${ }^{43}$. $\mathrm{O}$ wiele surowiej legislacja kościelna karała kazirodztwo.

$\mathrm{Na}$ straży wierności małżeńskiej stoi całkowity zakaz rozwodów. Małżeństwo trwa aż do śmierci współmałżonka. Rozwód jest przeciwny naturze i prawu Bożemu. Jest sprzeczny z naturą, ponieważ zawarcie małżeństwa doprowadza do naturalnego skutku, że współmałżonkowie stają się jednym ciałem i jakiekolwiek dążenie do separacji rani, bądź rozrywa tę jedność. Natomiast prawo Boże jest gwałcone, ponieważ to Bóg doprowadza do połączenia się małżonków ${ }^{44}$. Nawet jeśli życie w małżeństwie jest trudne, czy wręcz niemożliwe, rozwód jest niedozwolony ${ }^{45}$. Nawet prawodawstwo Mojżesza, które zezwalało na rozwód, nie mogło być punktem odniesienia w życiu chrześcijanina: jego bowiem obowiązuje nowe prawo - Chrystusowe, a nie to, które dane zostało Żydom na określony czas ze względu na zatwardziałość ich serc i na barbarzyńskie czasy. Prawo Mojżeszowe było tylko etapem i niejako wychowawcą człowieka ku przyjęciu nowego prawa i nowej moralności. Chryzostom twierdzi, że możliwość rozwodu w społeczeństwie Starego Testamentu była wprost konieczna, biorąc pod uwagę zdemoralizowanych Żydów wychodzących z wielobóstwa Egiptu. Hipotetyczny brak możliwości rozwodu w Starym Testamencie, mógłby według Chryzostoma prowadzić nawet do żonobójstwa w celu zawarcia nowego małżeństwa ${ }^{46}$.

Jan nie bierze w swojej nauce pod uwagę prawa świeckiego, które na rozwód pod pewnymi warunkami zezwalało ${ }^{47}$. Chrześcijanie mają kierować się innym prawem: Bożym, ono bowiem w ostatecznym rozrachunku zbawi lub potępi $^{48}$. Trudności małżeńskie i pokusa rozwodu w obliczu bezdyskusyjnego

tenże, De Anna sermo 1, 6, PG 54, 642-643; tenże, In epistulam 1 ad Thessalonicenses hom. 5, 2, PG 62, 425 .

${ }^{42}$ Por. Constitutiones Apostolorum VI 29, 4, ed. F. Funk, Paderborn 1905, 379-381; tamże VIII 32, 7, Funk, s. 534-535; tłum. S. Kalinkowski, ŹMT 42, 170 i 259.

${ }^{43}$ Joannes Chrysostomus, In Joannem hom. 63, 4, PG 59, 354, tenże, De libello repudii 2, 4 , PG 51, 224.

${ }^{44}$ Por. tenże, In Matthaeum hom. 62, 2, PG 58, 597-598: „ostendens illud et contra naturam et contra legem esse: contra naturam, quia una caro dissectatur; contra legem, quia Deus coniunxerit, et iusserit non separare, vos id facere tentatis".

${ }^{45}$ Por. tamże 6, 2, PG 58, 599: „nam valde onerosum videbatur uxorem omni nequitia plenam habere, et tolerare, indomitamque feram intus servare", thum. ŹMT 18, 80; tenże, De virginitate 44, 1, SCh 125, 253.

${ }^{46}$ Por. De virginitate 41, SCh 125, 237-239; tenże, In Matthaeum hom. 17, 4, PG 57, 260; 62, 1, PG 58, 597-598, tenże, In Isaiam hom. 1, 4, PG 56, 19.

${ }^{47}$ Por. Codex Theodosianus III 16, 1; zob. F. Cayré, Le divorce au IV siècle, „Échos d'Orient” 20 (1920) 296-303.

${ }^{48}$ Por. Joannes Chrysostomus, De libello repudii 2, 2, PG 51, 219: „ne mihi leges eb exteris 
prawa Bożego stają się okazją do wzajemnego przebaczenia sobie grzechów i wzmocnienia istniejącego związku. W wyniku pokonania trudności małżeństwo zajaśnieje na nowo jako obraz jedności Chrystusa z Kościołem ${ }^{49}$.

Nawet małżeństwo mieszane, gdy jedno z współmałżonków nawraca się na chrześcijaństwo, a drugie pozostaje poganinem, nie łagodzi tej zasady ${ }^{50}$. Separacja jest możliwa tylko w wypadku usiłowania ze strony pogańskiej nawrócenia na pogaństwo strony chrześcijańskiej, ponieważ zachowanie wiary jest $\mathrm{w}$ tym przypadku nadrzędne ${ }^{51}$. W takiej jednak sytuacji Jan nie mówi explicite o godziwości zawarcia drugiego małżeństwa. W normalnym pożyciu strona chrześcijańska ma za zadanie troszczyć się o przyjęcie wiary przez stronę pogańską

Można, twierdzi Chryzostom, oddalić cudzołożną żonę, ale ta nie ma możliwości nikogo pojąć za męża, dopóki jej prawowierny małżonek żyje: według prawa Bożego pozostaje bowiem jego prawowitą żoną ${ }^{53}$. To samo działa w drugą stronę ${ }^{54}$, aczkolwiek wydaje się, że podobnie jak inni Ojcowie wschodni, wyraża mniejszą pewność swego stanowiska, niż w wypadku zdrady małżeńskiej ze strony żony ${ }^{55}$. Znajdujemy bowiem u Jana teksty, które w tej sytuacji są przynajmniej niejasne, jeśli nawet nie przeczą same sobie ${ }^{56}$.

conditas legas, praecipientes dari libellum repudii, et divelli. Neque enim iuxta illas iudicaturus est te Deus in die illa, sed secundum eas, quas ipse statuit"; tamże 2, 3, PG 51, 222.

${ }^{49}$ Por. tenże, Quales ducendae sint uxores 2, PG 51, 228: ,etsi plurimum in te uxor peccaverit, totum ei remitte et condona: si male moratam nactus fueris, refinge eam ad bonitatem ac mansuetudinem, sicut et Christus Ecclesiam"; zob. tenże, De virginitate 40, 1, SCh 125, 233-235.

${ }^{50}$ Por. tenże, In epistulam 1 ad Corinthios hom. 19, 3, PG 61, 156: „Uxorem habens infidelem vocatus es? mane cum illa: ne propter fidem eicias uxorem".

${ }^{51}$ Por. tamże, 19, 3, PG 61, 155: „Verbi gratia si te iubet sacrificare aut sociam impietatis esse propter connubium, vel discedere; melius est disrumpi connubium, quam piam religionem"; zob. tenże, In Genesin hom. 26, 2, PG 53, 231-232.

${ }^{52}$ Por. tenże, In illud: Salutate Priscillam et Aquillam hom. 1, 3, PG 51, 192: „quo vero pacto fieri potest, ut mulier fidelis virum infidelem salvum faciat? Instruens nimirum illum et docens atque ad fidem adducans, sicut ista Priscilla Apollo"; tenże, In epistulam ad Titum hom. 4, 2, PG 62, 683; tenże, In Genesin sermo 5, 1, PG 54, 600.

${ }^{53}$ Por. tenże, In Matthaeum hom. 17, 4, PG 57, 259: ,,ne mihi dicas, ille eiecit, nam eiecta adhuc manet eicientis uxor", thum. ŹMT 18, 219; tenże, De libello repudii 2, 1, PG 51, 218.

${ }^{54}$ Por. tenże, In epistulam 1 ad Corinthios hom. 19, 2, PG 61, 154: „maneat uxor cum viro, etsi non ad concubitum, tamen ut nullum alium inducat virum"; tenże, In Matthaeum hom. 17, 4, PG 57 , 260: ,illa namque cum didicerit, prorsus necessarium esse, aut virum qui sibi ab initio sorte contigerat habere; aut si e domo illa egrediatur, nullum sibi aliud superesse refugium, vel invita cogetur coniugem amare suum", tłum. ŹMT 18, 220.

${ }^{55}$ Por. J. Moingt, Le divorce «pour motif d'impudicité» (Matthieu 5, 32; 19, 9), RSR 56 (1968) 338-349 i 375-384; H. Crouzel, Séparation ou remariage selon les Pères anciens, „Gregorianum” 47 (1966) 472-494.

${ }^{56}$ Por. Crouzel, Séparation ou remariage, s. 484; Joannes Chrysostomus, In Joannem hom. 63, 4, PG 59, 353: ,si quis cum meretrice coeat, unum cum illa corpus efficitur. Quomodo ergo honesta mulier, quae est membrum Christi, talem virum admittat? [...]. Illinc (matrimonio mixto) sanctitas 
Jest rzeczą oczywistą, że chrześcijaństwo w dziedzinę ludzkiej seksualności, a co za tym idzie życia małżeńskiego, wprowadziło całkiem nowe jakości w stosunku do świata pogańskiego. Jasne zasady wzywające do monogamii, wierności małżeńskiej, zakazu rozwodów, zakazu aborcji, czy porzucania nowo narodzonych dzieci brzmią aż nadto jasno począwszy od pierwszych pozakanonicznych pism chrześcijańskich. Jan Chryzostom w kontekście tych problemów rysuje się jako wybitny teolog i kaznodzieja, rozumiejący ważność uporządkowanego życia małżeńskiego i rodzinnego. Nazywając rodzinę mikroekklesia wprowadza niejako w jej strukturę jasne, ostre ewangeliczne zasady i w ten sposób stawia mocny fundament pod chrześcijańskie nauki o rodzinie ${ }^{57}$.

\section{LA FEDELTÀ CONIUGALE RECIPROCA NEL PENSIERO DI GIOVANNI CRISOSTOMO}

\section{(Riassunto)}

È ovvio che il cristianesimo introdusse nel vasto campo della sessualità umana e quindi anche nella vita coniugale alcuni valori totalmente differenti rispetto al mondo pagano. Le regole fisse che imponevano la monogamia, la fedeltà coniugale, divieto dei divorzi, dell'aborto, dell'omicidio dei neonati suonano chiaramente a partire dai primi scritti cristiani. Giovanni Crisostomo in questo contesto appare come un teologo e predicatore eccellente che conosce e capisce l'importanza della vita matrimoniale e familiare ordinata. In questa vita l'importanza della fedeltà dei coniugi costituisce un elemento fondamentale che va affirmato nell'educazione cristiana fin dalla giovinezza. Crisostomo, chiamando la famiglia mikroekklesia, intruduce nella sua struttura i chiari princípi evangelici e in questo modo costruisce un fondamento forte sotto l'insegnamento cristiano sulla famiglia.

manet, infideli cum illa habitante; hinc recedit"; tenże, In epistulam 1 ad Corinthios hom. 19, 3, PG 61, 155: „praeterea autem post fornicationem maritus non est ultra maritus”.

${ }^{57}$ Por. B. Częsz, Jan Chryzostom - teolog, TPatr 5 (2008) 11. 